\title{
単純性腎囊胞の臨床的検討
}

\author{
千葉大学医学部泌尿器科教室（主任：島崎 淳教授) \\ 安田 弥子 正井 基之 島崎 淳
}

\section{A SIMPLE RENAL CYST}

\section{Mitsuko Yasuda, Motoyuki Masai and Jun Shimazaki \\ Department of Urology, School of Medicine, Chiba University \\ (Director: Prof. J. Shimazaki)}

Incidence of simple renal cysts was calculated in 30,316 patients receiving routine ultrasound examination in one hospital, and 170 cases visiting Chiba University Hospital were further analyzed in terms of their clinical features. Incidence of simple renal cyst was $14 \%$ in all populations and ratio of male to female was 1.6:1. Patients age ranged from 8 to 92 years (average age 58.6 years) and number of a renal cyst was increased after fifth decade in both sexes. Patients of Chiba University Hospital were examined on symptoms and clinical courses with maximal follow up to 132 months (average 18 months). Symptoms associated with simple renal cysts were: none (75.3\%) pain (14.7\%) and gross hematuria (6.4\%). Uninalysis of patients without associated urinary diseases, showed microhematuria in $40 \%$ and proteinuria in $12 \%$, however, grade of microhematuria and proteinuria was not correlated with size of cysts. Number of cysts tended to increase with age. Size of cysts and rate of enlargement were increasing along with age. In any cases, renal function was not and affected nor occurred malignant tumor during follow-up period. Cyst punctures with screlosing agent were performed in 16 patients, and most of the cysts remained the seme as or exceeded their original size. It is concluded that routine follow-up is sufficient in most cases without symptoms, since simple renal cysts increase slowly, and impairment of renal function and progression to malignant tumors do not occur.

Key words: simple renal cyst, cystic disease

\footnotetext{
要旨：単純性腎囊胞の頻度を一関連病院で腹部一般検査の一つとして行われた超音波検査症例 30,316 例 を対象として算出した。更に千葉大学医学部附属病院を受診した170例について臨床像を検討した。単純 性腎囊胞の頻度は14\%で男女比は1.6：1であった。年齢は 8 歳から92歳, 平均 58.5 歳で男女とも50歳以 降に増加した。千葉大学症例について症状及び経過について検討した。観察期間は最長 132 月，平均 18 カ月であった。腎囊胞に関連すると思われた症状は無症状 $75.3 \%$, 疼痛 $14.7 \%$, 肉眼的血尿 $6.4 \%$ あ゙あっ た.

泌尿器疾患の合併のない症例の初診時尿所見では顕微鏡的血尿は $40 \%$ に蛋白尿は $12 \% に$ 見られたが， その重症度と㐮胞径との間に相関はなく腎囊胞との因果関係は少ないと推測した.

腎囊胞の個数は年齢と共に増加する傾向があった。また腎囊胞の囊胞径及び体積増加率は年齢と共に 増加し有意な相関を示した。

観察期間中に腎機能の悪化した例はなく悪性化も認めなかった。囊胞が比較的大きく疼痛を訴えた16 例に囊胞穿刺術が行われたが，汪とんどの症例で穿刺前の体積と同じかそれ以上になっていた。

囊胞の大きさ及び個数は年齢と共に増すがその变化は緩徐であり, 腎機能もほとんど障害されないの で大部分の症例では経過観察のみで良いと考光た。

キーワード : 単純性腎囊胞, 囊胞性腎疾患
}

緒言

腎囊胞，特に単純性腎囊胞は腹部超音波検査や CT
の普及により日常よく経験する疾患であるが，臨床上 問題となることが少ないため放置されており，その経 
過についてはあまり検討されていない，近年症状を有 するものに対して超音波ガイド下の腎囊胞穿刺術及び 硬化剂の注入療法が行われるようになってきたが，無 症状のものに対しては処置の必要性について意見の分 かれるところである，今回，単純性腎囊胞の頻度，症 状，及び自然経過について臨床的検討を行った。

\section{対象と方法}

1981年から1990年末でに千葉大学医学部附属病院泌 尿器科を受診し外来にて単純性腎襄胞と診断された 170例を対象とし，症状，尿所見，年齢と大きさ及び個 数の関係について検討した。このらち無症状のため 1 年以上無処置で経過観察した 50 例（ 1 年〜 11年，平均 4.8年)について囊胞の変化を経時的に観察した。診断 には主として超音波装置 SSD-630 Aloka を用い, 一部 はCTやMRIを併用した。囊胞径は超音波画像上の 最大面積における長径で示した。 また，体積は超音波 画像上の最大面積における長径と短径及びその相加平 均より楕円体として求めた。腎囊胞は単純性, 多房性, および傍腎孟囊胞の 3 型に分類し，本研究では単純性 のもののみをとりあつかった，腎囊胞の頻度について は, 当科受診患者を母集団とすると泌尿器疾患に限ら れるため，腹部一般検査の一つとして旭中央病院で 1985年から1990年に全科依頼により実施された超音波 検査症例 30 ,316例を対象として算出した。これらの大 多数は内科的疾患であり, 泌尿器科的症状を欠くもの であった。

\section{結 果}

千葉大学泌尿器科の検討期間にお打る囊胞性腎疾患 は単純性腎囊胞170例 (84\%), 多房性腎囊胞 3 例 (1\%)，傍腎孟霅胞29例（15\%）であった。このうち 単純性腎囊胞（以下，腎霊胞）について検討した。患 者の年龄別, 男女別分布を図 1 に示す。170例の5ち男 性 $62 \%$, 女性 $38 \%$, 男女比は1.6：1であった。年齢は $8 \sim 92$ 歳平均 58.5 歳で男女とも50歳台に多く見られ た。次に腎囊胞の頻度について, 旭中央病院の全科に おいて一般検査の一つとして実施された腹部超音波所 見で算出した。男性 15,407 例, 女性 14,909 例, 計 30,316 例のうち腎囊胞を見出されたものは 4 ,188例（13.8\%） であり，男性 $16.7 \%$ ，女性 $10.8 \%$ であった(表 1)。腎 囊胞は 20 歳以下ではまれで30歳台より増加し始め, 70 歳以上では男性 $36 \%$ ，女性 $22 \% ，$ 全体で $29 \%$ に見られ た（図 2 ）。霅胞保有者数は, 男女比 $1.6 ： 1$ で各年代 において男性の方が女性より多く, 男女とも60歳台が ピークで千葉大学症例とほぼ同様の傾向を示した。
図 1 単純性腎囊胞の年齢別性別分布

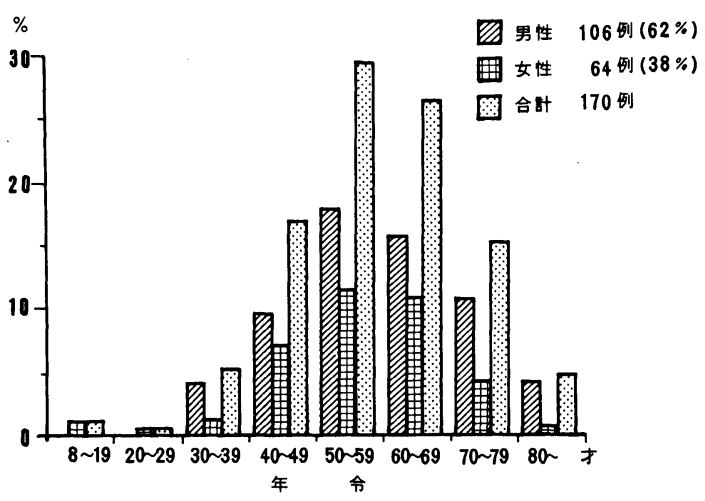

表 1 腎囊胞の年齢別頻度（腹部一般検査による算出）

\begin{tabular}{cccr}
\hline & \multicolumn{1}{c}{ 男 } & 女 & \multicolumn{1}{c}{ 計 } \\
\hline $0 \sim 9 才$ & $0 / 188(0 \%)$ & $1 / 249(0.4 \%)$ & $1 / 437(0.2 \%)$ \\
$10 \sim 19$ & $8 / 500(1.6)$ & $10 / 610(1.6)$ & $18 / 110(1.6)$ \\
$20 \sim 29$ & $41 / 896(4.6)$ & $36 / 1019(3.5)$ & $77 / 1915(4.0)$ \\
$30 \sim 39$ & $165 / 2489(6.6)$ & $87 / 1948(4.5)$ & $252 / 4437(5.7)$ \\
$40 \sim 49$ & $322 / 2998(10.7)$ & $183 / 2668(6.9)$ & $505 / 5666(8.9)$ \\
$50 \sim 59$ & $601 / 3516(17.1)$ & $374 / 3401(1.0)$ & $975 / 6917(14.1)$ \\
$60 \sim 69$ & $670 / 2687(24.9)$ & $474 / 2996(15.8)$ & $1144 / 5683(20.1)$ \\
$70 \sim 79$ & $618 / 1769(34.9)$ & $359 / 1638(21.9)$ & $977 / 3407(28.7)$ \\
$80 \sim$ & $153 / 364(42.0)$ & $86 / 380(22.6)$ & $239 / 744(32.1)$ \\
\hline & $2578 / 15407(16.7)$ & $1610 / 14909(10.8)$ & $4188 / 30316(13.8)$
\end{tabular}

図 2 腎囊胞の年齢別頻度（腹部一般検査による算出）

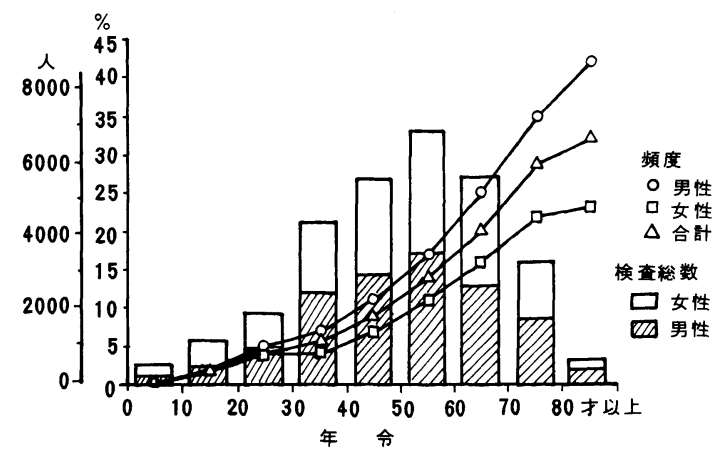

症状，経過及び処置については千葉大学症例につい て検討した。腎囊胞のみに関係すると思われた愁訴で は無症状が75.3\%で最も多く，これは尿潜血や腹部超 音波検查で腎囊胞を指摘されたりして精査目的に受診 したものであった(表 2 )。次いで疼痛が $14.7 \%$ ，肉眼 的血尿 $6.4 \%$, 腹部膨満感 $2.4 \%$, 発熱 $1.2 \%$ で蛋白尿は なかった。泌尿器疾患の合併は $44.1 \%$ に見られ尿路結 
表 2

単純性腎裳胞のみに関連すると

思われた愁訴 : 170 例

$\begin{array}{lcl}\text { 無症状 } & 128 \text { 例 } & (75.3 \%) \\ \text { 疼痛 } & 25 & (14.7) \\ \text { 肉眼的血尿 } & 11 & (6.4) \\ \text { 腹部㬨满感 } & 4 & (2.4) \\ \text { 発熱 } & 2 & (1.2 ）\end{array}$

泌尿器合併疾患 : 76 例 $(44.7 \%)$

$\begin{array}{ll}\text { 尿路結石 } & 32 \text { 例 } \\ \text { 前立腺肥大症 } & 15 \\ \text { 前立腺资 } & 8 \\ \text { 慢性糸球体堅炎 } & 6 \\ \text { 慢性膀胱炎 } & 4 \\ \text { 珁癌 } & 3 \\ \text { 尿道カルンクルス } & 2 \\ \text { 前立腺癌 } & 2 \\ \text { 膀胱癌 } & 2 \\ \text { 神経因性膀胱 } & 2\end{array}$

図 3 血尿と囊胞径

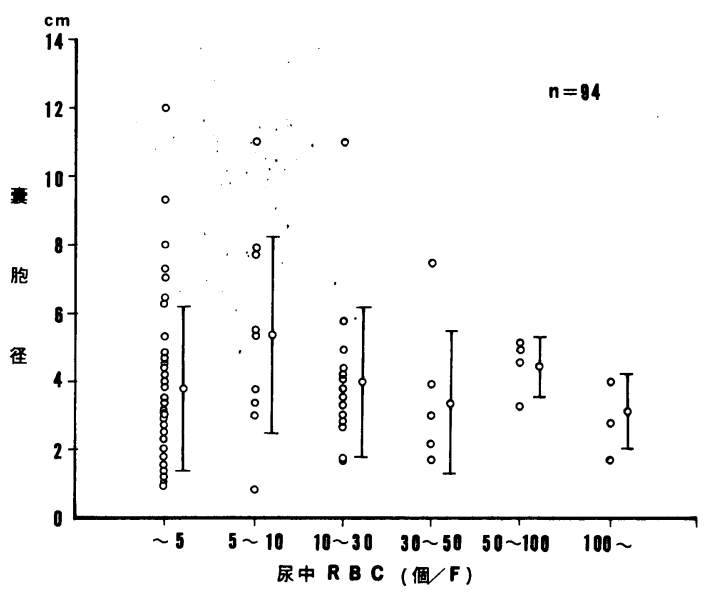

石が最も多くついで前立腺肥大症, 前立腺炎, 慢性系 球体腎炎であった，尿路結石がもっとも多いのは，尿 路結石患者に外来で超音波検査を施行する機会が多

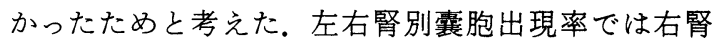
43\%, 左腎39\%, 両側18\%で, 左右差を認めなかった。 泌尿器疾患の合併のない.94例で初診時尿所見を検討 した. 赤血球 5 個以上の顕微鏡的血尿は $40 \%$ に見られ た。 また $30 \mathrm{mg} / \mathrm{dl}$ 以上の蛋白尿は $12 \%$ に見られた。血 尿の程度と囊胞径の関係を図 3 に示した。両者間に相 関は認めなかった。蛋白尿の程度と囊胞径の関係を困
図 4 蛋白尿と囊胞径

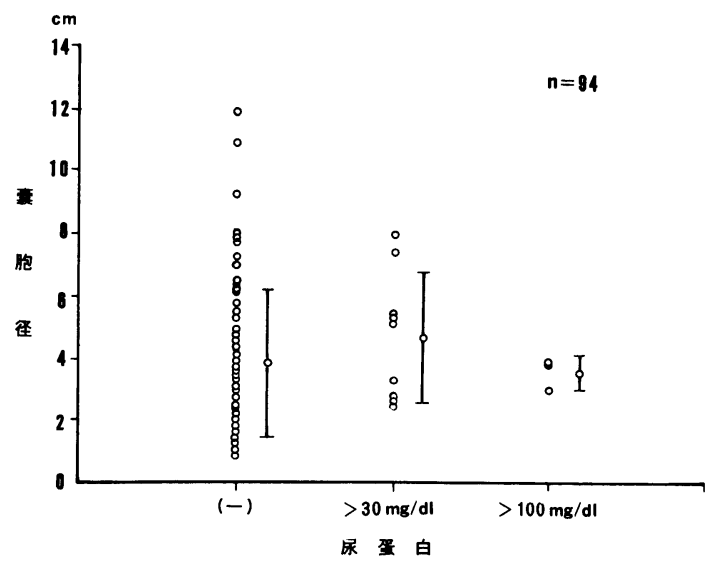

図 5 単純性腎囊胞の年㯝々個数

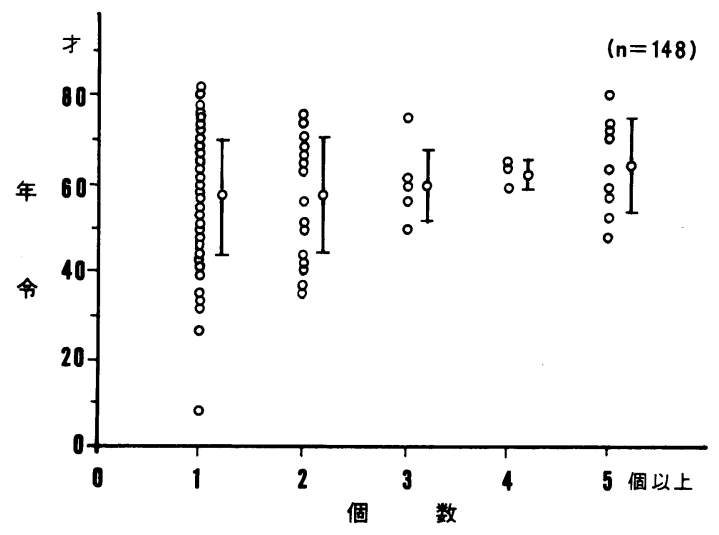

4 に示した。両者間に相関は認めなかった。これより 顕微鏡的血尿や蛋白尿は囊胞と直接関係ないと考学 た。

腎囊胞の初診時の年歯と個数では, 年齢と共に個数 が増加する傾向を示した(図 5 )。初診時における年齢 と囊胞径との関係を検討した（図 6 ). 囊胞が複数の場 合は最大のものを囊胞径とした。両者は相関を示し， 囊胞径は年齢とともに増加した。単純性腎囊胞が高年 齢で大きくなりやすいかどらかについて 1 年以上無処 置のまま経過観察した50例で囊胞の経時的変化を検討 した(図 7 ). 各症例は 1 年に数回測定されたものも含 むが，年 1 回の計測值によって図示した。年齢の増加 に従って囊胞径の増大を示す例が多くみられた。これ より体積増加率と初診時年齢との関係をみた。体積増 加率は初診時と終診時の囊胞体積の差を観察期間で割 り，便宜上 3 カ月に打ける増加率とした(図 8 ). 年齢 
図 6 単純性腎囊胞の年齢と囊胞径

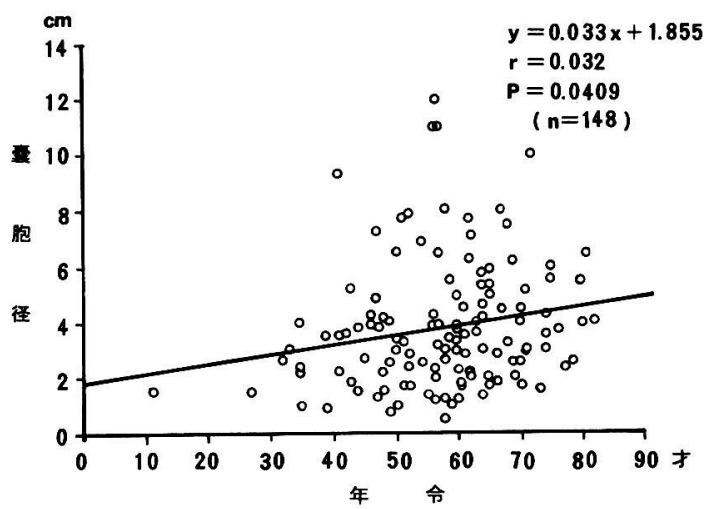

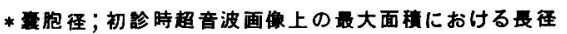

図 7 単純性腎囊胞の体積の経時的変化

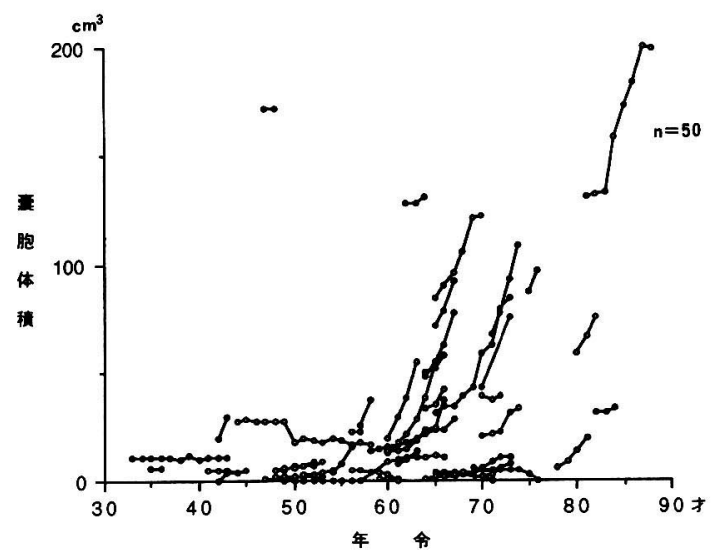

図 8 単純性腎囊胞の年齢と体積増加率

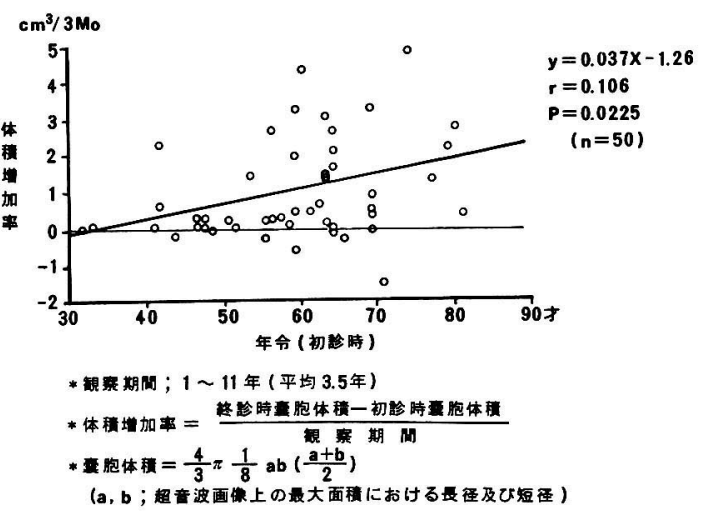

と体積増加率はよく相関し, 体積増加率は, 年齢とと もに増加した。

130例について無処置のまま 3 力から11年（平均
1.5年)にわたり自然経過を観察した。この間定期的に PSP たた C cr を実施した結果, 腎機能の悪化した例 はなくまた悪性化も見られなかった。

囊胞が比較的大きく疼痛を訴えた16例につき超音波 ガイド下に経皮的囊胞穿刺術を行った。これらに対し ては吸引のみで硬化剂の注入を実施しなかった。この らち穿刺術後の経過観察が可能であった11例について 穿刺術後の体積の変化を検討した(図 9). 観察期間は 2 力月から 10 年平均 5.1 年で平均 4.7 月の間に大部分 が再発した。また，1年以上経過観察したほとんどの 症例で穿刺術前の体積と同じかそれ以上になってい た.

経皮的囊胞穿刺術以外に症状の軽減末たは合併疾患 の治療を目的として手術を実施したものは12例で，翼 胞壁切除術 8 例, 腎摘出術 4 例であった。腎摘出術を おこなったものは，いずれも尿路疾患により高度の閉 塞に陥った結果の無機能腎であった。

図 9 霬胞穿刺後の体積の変化

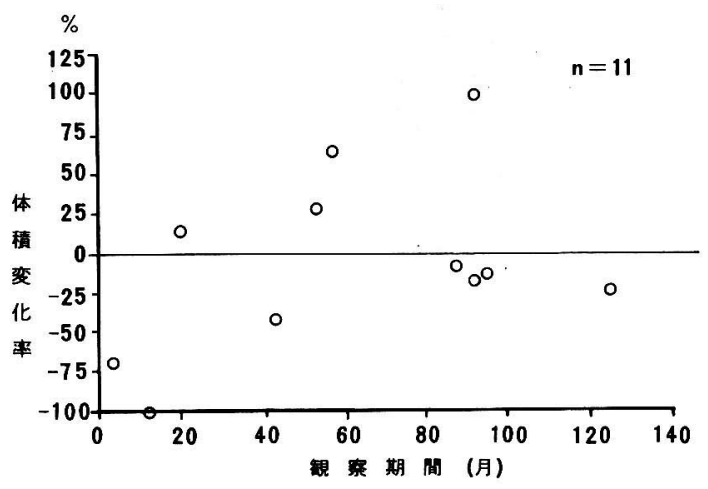

図10 囊胞壁の組織学的所見：囊胞壁は一層の扁平化 した立方細胞よりなり脱落している部分も多い（X 100).

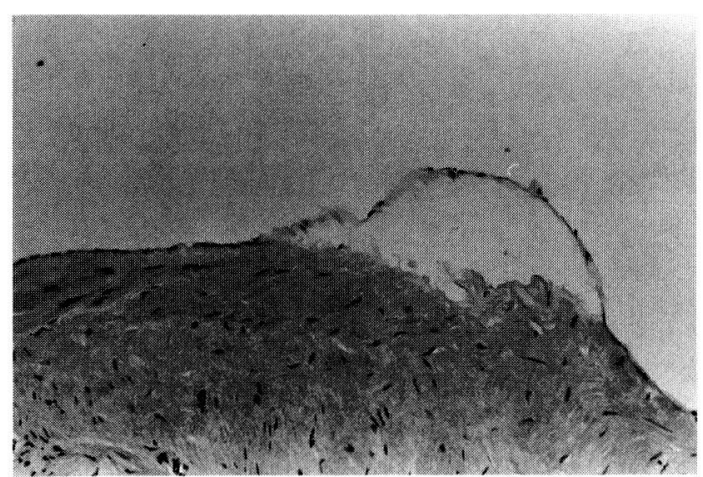


手術例における組織学的検索で, 囊胞壁は立方形を 示す一層の上皮細胞と結合織よりなり(図10), 乳頭状 などの増殖性変化は認めなかった。上皮細胞は囊胞内 圧により扁平化しており，また脱落した部分が多く， 囊胞の由来は不明であった。

\section{考察}

$\operatorname{Hartman}^{11}$ は腎の囊胞性疾患を 7 種類に分類し, 先 天性のものとして囊胞腎, Medullary cystic kidney, Multicystic dysplastic kidney, Renal cysts in syndromes of multiple malformationを, また後天性の ものとして単純性腎囊胞(多房性腎囊胞を含む), 傍腎 孟囊胞, 多囊胞化萎縮腎をあげている。単純性腎囊胞 は Gordon らの診断基準によると，（1）囊胞が単房性 で孤立性である，(2) 家族歴が無い，(3) 尿路との交 通が無い（4）囊胞内容液は黄色透明で悪性細胞を含 まない（5）囊胞壁は平滑で一層の上皮細胞と線維組 織より成ることがあげられる21．囊胞が両腎に多発す る場合に常染色体優勢遺伝である囊胞腎との鑑別が困 難なことがあり家族歷が問題となってくる．傍腎㙉囊 胞は腎洞に位置し腎実質を介さず直接，腎孟と接する 囊胞であり，その成因についてはリンパ系の閉塞・拡

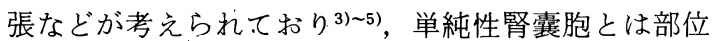
を異にする。

Hartmanは多房性腎囊胞を単純性腎囊胞の亜型と しているが，その成茵については現在腫瘍説が有力で あり単純性腎囊胞とは区別されている ${ }^{6}$. 多房性腎露 胞は超音波診断技術の進歩に伴い囊胞内の隔壁が描出 可能となり以前ほどまれなものではなくなった。単純 性腎囊胞はこれら 2 つ超音波検査, CT, MRI などで 鑑別可能となった．多囊胞化萎縮腎は長期透析患者の 両腎に囊胞が多発するものである。

単純性腎囊胞は, 囊胞性腎癌や囊胞腎の初期の段階 との鑑別が重要である。腎囊胞の $2 \sim 7 \%$ に悪性腫瘍 が合併するが78)，囊胞が腫瘍化するかどうかについて は明らかではない，石川らは長期透析患者の多囊胞化 萎縮腎に合併した腎癌 3 例を報告し，全例で囊胞壁に 腺腫が存在していたことから, 腎囊胞が腫瘍化する可 能性を説明できるとしている 性腎囊胞の経過において悪性への進展をみなかった。 また一部症例の囊胞の組織学的検査でも全く上皮の増 殖性变化が無かった。 そのため単純性腎囊胞は悪性化 しないと推測した。しかし，多房性腎囊胞については 腫瘍合併が警告されている6. 従って, 単純性腎囊胞で あっても囊胞壁に肥厚や不整，石灰化などがみられる
場合は, 厳重な経過観察が必要であり, 病変部に増大 傾向を認めた場合，積極的な検査や処置を行うべきで あろう。

単純性腎囊胞は腹部超音波検査や CT 施行頻度の増 加に伴い，外来や健康診断で比較的よく経験するよう になった。腎囊胞の頻度は検査方法及び検査対象の違 いによって異なる. Kissane は50歳以上の剖検例の $50 \%$ 以上に腎囊胞が見られたとしている，腹部 CT で

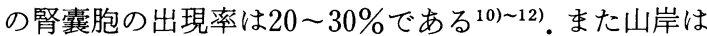
腎疾患を伴わない外来患者348例の超音波検査で47例 $13.5 \%$ 腎囊胞が発見され，その頻度は年齢とともに 増加したとしている ${ }^{13)}$. 伊藤らは4,094例の一般健康診 断に打ける超音波検査を報告し, $2.1 \%$ に腎囊胞が発見 されたとしている ${ }^{14)}$. 本研究に打いて全検査対象の $13.8 \%$ 腎囊胞が見られ，その頻度は30歳台より増加 し，70歳以上では $30 \%$ 之高率を示し，年齢との相関を 認めた。腎囊胞は女性より男性に多いとされている が12)，これは全年代に共通していた. 10歳未満での頻度 は $0.2 \%$ あっあたが，小児科領域における超音波検査が 日常的になれば，発見率も増すと思われている1516).

伊藤らは腎囊胞例の約 $1 / 6$ に尿沈椬で赤血球 $3 / \mathrm{HPF}$ 以上の血尿を認め，これは一般健康人に打ける血尿の 頻度よりはるかに多いと考えられるので腎囊胞は血尿 の原因になるとしている ${ }^{14}$. 今回, 腎囊胞の $40 \%$ に尿沈 渣で赤血球 $5 / \mathrm{HPF}$ の血尿を認めた。囊胞による局所組 織や腎動脈への圧迫が局所の虚血をもたらし，系球体 基底膜になんらかの変化をきたす可能性はあるもの の, 囊胞径と血尿の程度の間には相関は認めなかった。 従って腎囊胞は顕微鏡的血尿の直接の原因とは考号難 い。をた蛋白尿と腎囊胞の関係を見なかった。血尿， 蛋白尿とも腎囊胞と偶然に合併した可能性が高いと推 測される。

腎囊胞は後天的なものとされているが，その成因に ついては解明されていない. Heplerや Baert らは加 齢によって動脈硬化による腎の虚血や髄質間質の線維 化，基底膜の脆弱化が起こり，遠位尿細管や集合管が 憩室化して囊胞が形成されるとしている(1017)18)。しか し組織学的にみた結果では囊胞上皮の変化が強く, 正 常組織との類似性を見ることはできなかった。腎囊胞 は男性に多く見られるが，前立腺肥大症などの尿路通 過障害が囊胞形成の促進因子となるといら説があ $3^{17718)}$ ．囊胞の加齢に伴う自然経過については最大径 および個数ともに年齢と共に増加するという報告が多 (10)14)15). 今回も腎囊胞の頻度は年齢とともに増加し 
たが，囊胞は動脈硬化や尿路通過障害が目立つ以前よ り増加するので, これらと直接の因果関係は考学難い. 山岸は囊胞の最大径は年齢と共に増加する傾向があっ たが有意な相関は認めなかったとしている ${ }^{13)}$.今回の 検討では最大径, 及び体積増加率ともに年齢と共に有 意な増加を見たが，この相違は怙そらく検討症例数の 違いによるものであろう。

腎囊胞に対して経皮的腎囊胞穿刺術が行われている が, 囊胞の穿刺及び吸引のみでは再発が見られている。 今回, 穿刺術のみを行った症例の経過でも囊胞は術前 之同じかそれ以上に増大している。近年，再発予防の 目的で種々の硬化剂の注入療法が試みられてお $\eta^{201 \sim 25)}, 95 \%$ ェタノール注入療法は代表的なものであ る。本報の対象症例以外で, 有症状の単純性腎囊胞に 対してェタノールの注入を行っており, 囊胞の増大の 停止を確認している。しかし, 単純性腎囊胞は加齢と ともに大きさ, 数ともに増加するがその变化は緩徐で あり, 腎機能もほとんど障害されないので症状を欠く 大部分の腎囊胞は放置のままで良いと考光た。しかし， 疼痛などの症状を有するものに対しては経皮的腎囊胞 穿刺術及び硬化剂注入療法の適応となろう。

\section{結 語}

（1）単純性腎囊胞の頻度は一般検査に抢いて $13.8 \%$ で年歯と共に増加し，とくに50歳台以降に上昇した。 全年代に打いて男性の方が女性より多く，1.6：1で あった。

（2）腎囊胞に関係すると思われる愁訴では無症状が $75.3 \%$ あったがついで疼痛, 肉眼的血尿となった。

顕微鏡的血尿及び蛋白尿の重症度と囊胞径の間に相 関はなく，囊胞との因果関係は少ないと推測した。

腎囊胞の個数は年齢と共に増加する傾向があった。

（3）腎囊胞の囊胞径及び体積増加率は年齢と共に有 意に増加した。

経過観察中に腎機能の悪化した例はなく，悪性化も 見られなかった。しかし，囊胞穿刺術及び吸引のみで はほとんど再発を見た。

（4）以上より多くの単純性腎囊胞は無処置で経過観 察を行らことで十分であると結論した。

稿を終えるにあたり, 御協力戴いた旭中央病院泌尿器科 村上信乃部長, 同五十嵐辰男医長に感謝の意を表します。

\section{文献}

1) Hartman, D.S. : Renalcystic Disease, 1th ed., p. 2, Saunders Co., Philadelphia, 1989.

2) Pearl. M. and Klein, S.: Symple renal cyst and hypertension. Ann. Radiol., 29, 421-423, 1986.

3）山本松男, 山崎武成, 黒住武史, 八木拡朗, 尾本徹 男：傍腎孟囊胞の 3 例. 西日泌尿, 51, 1273-1277, 1989.

4）松岡俊介, 福島修司, 小川勝明, 岩本晃明：Parapelvic cyst $の 1$ 例。臨泌，27，935-939，1973.

5）古川洋二, 田中啓幹：傍腎盂囊胞に上る水腎症の 1例. 臨泌, 45, 529-531，1991。

6）三宅 修, 福岡敏雄, 吉岡俊昭, 松田 稔, 徳永 仰: 多房性腎囊胞の 1 例. 泌尿紀要, 35, 1569-1572, 1989.

7）植田省吾, 松浦省三：腎細胞癌を伴う孤立性腎囊 胞の 1 例. 西日泌尿, 43，561-566， 1986.

8）田中 聡, 小林大樹, 工藤誠治, 工藤達也, 古川利 明, 鈴木唯司：巨大腎囊胞に合併した腎細胞癌. 臨 泌，45，229-231， 1991.

9）宮本忠幸，小林文都，橋本寛文，竹中 章，寺尾尚 民：長期透析患者に発生した腎細胞癌の 2 例。西 日泌尿，51，1999-2002，1991。

10) Laucks, S.P. Jr. and McLachlan, M.S. : Aging and simple cysts of the kidney. $\mathrm{Br}$. J. Radiol., 54, 12-14, 1981.

11) Tada, S., Yamagisi, J., Kobayasi, H., Hata, Y. and Kobari, T.: The incidence of simple renal cyst by computed tomography. .Clin. Radiol., 34, 437-439, 1983.

12）高麗文晶, 山子勇化, 吉田秀策, 鴻池 尚：腎の単 純囊胞と加齢。臨放， 30，385-389，1985.

13) Yamagisi, F., Kitahara, N., Mọgi, W. and Itoh, S.: Age-related occurence of simple renal cysts studied by ultrasonograpy. Klin Wochenschr., 66, 385-387, 1988.

14）伊藤晴夫, 柳 重行, 山口邦雄, 座間秀一, 藤田良 一：一般健康人における腎疾患の頻度. 泌尿紀要, 34, 66-68, 1988.

15) Orton, K. and Smith, J.A. Jr.: Simple renal cysto in children. J. Pediatr. Surg., 20, 543-546, 1985.

16) Steinhardt, G.F., Solvis, T.I. and Perlmutter, A. D. : Simple renal cysts in infant. Radiology, 155, 349-350, 1985.

17) Baert, L. and Steg, A.: Is the diverticulum of the distal and collecting tubules a preliminary of the simple cyst in the adult? J. Urol., 118, 708-710, 1977

18) Baert, L. and Steg, A.: Diverticula on distal tubule, simple renal cysts, and ureteral obstruction. Urology, 11, 221-224, 1978.

19) Lusher, T.F., Wannner, C., Siegenthaler, $W$. and Vetter, W.: Simple renal cyst and hypertension : Cause or coinsidence? Clin. Nephrol., 26, 91-95, 1986. 
20）川村寿一, 日裏 勝, 郭俊逸, 畑山 忠, 蔦巣腎 一, 喜多芳彦, 寺井章人, 小川 修, 岡村泰彦, 大 石賢二, 東 義一, 岡田謙一郎, 吉田 修, 桑原智 美, 上田政雄: 経皮的腎囊胞穿刺飞よる $95 \%$ 工 タール注入療法。泌尿紀要, 30, 589-598, 1984.

21）福崎 篤, 沼田 功, 折笠精一: 霊胞腎の進展要因 の検討之経皮的腎囊胞縮小術の効果. 日泌尿会誌, 80, 1489-1496, 1989.

22) Lange, E.K.: Renal cyst puncture studies. Urol. Clin. North Am., 14, 91-102, 1987.

23) Bean, W.J.: Treatment with alcohol. Radiol., 138, 329-331, 1981.
24）篠田育男, 石原 哲，竹内敏視，高橋義人，山羽正 義, 兼松 稔, 栗山 学, 坂 義人, 河田幸道, 山 田伸一郎, 説田 修, 篠田 孝: 腎囊胞に対する経 皮的 povidon iodine 注入療法. 泌尿紀要, 34, 1741-1745, 1988.

25）岡所 明, 山本秀和, 浅利豊紀, 西東康夫, 小坂哲 志, 島村正喜, 宮城徹三郎, 沢木 勝, 庄田良中, 小泉久志, 大川光央：単純性腎囊胞に対する塩酸 ミノサイクリンの経皮的注入療法. 泌尿紀要, 33, 1162-1166, 1987.

（1992年 9 月 8 日受理，特別掲載） 